Інноватика у вихованні. Випуск 11. Том 1. 2020.

УДК 378.016:5

DOI: $10.35619 /$ iiu.v1i11.233

Сяська Інна

кандидат педагогічних наук, доцент, докторант кафедри теорії і методики виховання Рівненського державного гуманітарного університету, м.Рівне, Україна ORCID: 0000-0002-6096-1335 e-mail: syaskainna@gmail.com

\title{
ШЛЯХИ ПІДВИЩЕННЯ ЯКОСТІ НАВЧАЛЬНО-ДОСЛІДНИЦЬКОЇ ПІДГОТОВКИ МАЙБУТНІХ УЧИТЕЛІВ ПРИРОДНИЧИХ ДИСЦИПЛІН
}

\begin{abstract}
Анотація. У статті здійснено аналіз практики фахової підготовки вчителів природничих наук у Європі та Україні. Охарактеризовано ті дослідження, які акцентують увагу саме на важливості навчально-дослідницької підготовки майбутніх вчителів у галузі природничих наук та відповідають сучасним освітнім потребам. Встановлено, що у контексті зазначеної проблеми прогресивним можна вважати досвід Фінляндії, де організація підготовки вчителів природничих наук здійснюється із застосуванням мультидисциплінарного підходу та залученням педагогічних технологій, які дають змогу у навчальному процесі поєднувати одночасно теоретичну i практичну підготовку майбутнього фахівця шляхом спрямування іiі на дослідно-орієнтовану практичну діяльність. Обгрунтовано методичні підходи до створення спеціального освітнього середовища 3 метою підвищення якості навчально-дослідницької підготовки в освітньому процесі закладів вищої педагогічної освіти України. Визначено форми, засоби й технології iii реалізації в освітньому процесі Рівненського державного гуманітарного університету. Доведено, що навчально-дослідницька діяльність студентів у лабораторіях навчально-методичного центру природничої освіти зумовлює розвиток низки професійних компетентностей та soft-skills навичок майбутніх вчителів природничих дисциплін.
\end{abstract}

Ключові слова: заклад вищої педагогічної освіти, учитель природничих дисциплін, освітнє середовище, навчально-методичний центр природничої освіти, навчально-дослідницька діяльність.

Постановка проблеми. Одним із пріоритетних завдань нової української школи $\epsilon$ формування сучасного природничо-наукового світогляду учнів, здатних оцінювати практичне значення наукових досягнень різних галузей природознавства у житті людини і суспільства, розуміти морально-етичні й соціальні аспекти природничих досліджень, їх вплив на здоров'я людини i навколишнє середовище. Забезпечити реалізацію означених стратегічних завдань спроможний педагог, який має грунтовні інтегровані природничі знання, може здійснювати ефективну педагогічну взаємодію 3 учнями, володіє розвинутими уміннями й навичками науково-дослідної роботи та ефективно використовує інноваційні педагогічні технології. Відтак, створення відповідного освітнього середовища та матеріально-технічних умов забезпечення навчально-дослідницької підготовки майбутніх учителів природничих дисциплін $є$ одним із пріоритетних напрямів діяльності закладу вищої педагогічної освіти та потребує детального вивчення.

(C) Сяська I., 2020 
Аналіз основних досліджень 3 проблеми. Проблемами фахової підготовки майбутніх учителів природничих дисциплін (біології, фізики, хімії) й, зокрема, розвитку їх навчально-дослідницьких навичок у різний час займалися низка вітчизняних і зарубіжних вчених: Л. В. Бурчак, М. М. Верзілін, М. В. Гриньова, І. Л. Дрижун, В. С. Єлагіна, Т. С. Куратова, В. М. Корсунська, І. В. Мороз, В. В. Оніпко, В. М. Пакулова, Б. Є. Райков, М. Ю. Солощенко, С. В. Стрижак, О. Г. Ярошенко, Ј.P. Astolfi, W. Stawiński, M. Švecová, P. Tarhon й ін. Реформа середньої освіти, яка здійснюється нині, потребує зміну підходів до підготовки вчителів-предметників згідно вимог компетентнісно-орієнтованої європейської освіти. Відповідно визначення методичних підходів до створення освітнього середовища у закладі вищої педагогічної освіти $з$ метою підвищення якості навчально-дослідницької підготовки майбутніх учителів фізики, хімії, біології, природознавства стало метою нашого дослідження.

Виклад основного матеріалу дослідження. Практика фахової підготовки вчителів природничих наук за кордоном і в Україні має певні відмінності. Зупинимося на характеристиці тих досліджень, які акцентують увагу саме на важливості навчальнодослідницької підготовки майбутніх вчителів у галузі природничих наук та відповідають сучасним освітнім потребам.

Зокрема, західноєвропейська практика навчання майбутніх учителів спрямована на інтегровану підготовку фахівців (Франція, Великобританія, Ірландія, Данія, Фінляндія). До прикладу, у Франції не готують вчителів біології, фізики чи хімії, а підготовка студентів здійснюється за напрямом «Науки про життя та землю». Випускники-магістри Вищих шкіл викладацького складу й освіти (ESPE) за цим напрямом можуть викладати природничі дисципліни у закладах середньої освіти Франції, які попередньо пройшли підготовку 3 професійноорієнтованих дисциплін та виконали науково-дослідницьку роботу, а також успішно завершили стажування й конкурсний відбір на посаду вчителя. Незважаючи на доволі значні відмінності у змісті професійної підготовки педагогів у різних закладах освіти, обов'язковими до вивчення є декілька базових курсів. Серед них вирізняється «Дидактика природничих наук», яка співзвучна із звичними для нас методиками навчання фізики, хімії, біології, та опирається на сучасні досягнення природничих наук у поєднанні з психолого-педагогічними підходами до їх презентації викладання. Особливе місце у науковому і навчальному забезпеченні викладання цієї дисципліни займають праці професора Жана-П'єра Астольфі (1996), у яких значна увага відводиться як методичній, так і навчальнодослідницькій підготовці майбутнього вчителя природничих наук.

Підготовка вчителів Великобританії згідно положення Department for Education and Skills / Teacher Training Agency (2002) є двоступеневою і частково відповідає українській системі: передбачає навчання у педагогічних коледжах з отриманням ступеня «Бакалавра педагогіки» та за потреби подальше здобуття університетської освіти з отриманням ступеня бакалавра, приміром, природничих наук. У такому випадку навчання може здійснюватись як за програмами однорічної підготовки, так і дво-, і чотирирічної залежно від отриманої кваліфікації випускника з правом працювати лише в початковій, початковій і середній, середній та вищій школах. У професійній підготовці вчителів вирізняється поєднання предметно спеціалізованого і практично спрямованого навчання, яке реалізується насамперед в актуалізації навчально-дослідницької діяльності студентів. Вони мають змогу практикувати іiі безпосередньо у школі під прямим керівництвом викладачів університетів. Отримання відповідної педагогічної кваліфікації випускниками університетів можливе лише за умови успішного проходження однорічного стажування у школі. 
У контексті зазначеної проблеми прогресивним вважаємо досвід Фінляндії. Організація підготовки вчителів природничих наук здійснюється із застосуванням мультидисциплінарного підходу та використанням педагогічних технологій, які дають змогу у навчальному процесі поєднувати одночасно теоретичну й практичну підготовку майбутнього фахівця через спрямування іiі на дослідно-орієнтовану практичну діяльність.

За результатами вивчення та аналізу практики підготовки майбутніх учителів початкової школи, К. В. Котун (2014) дійшов висновку, що розвиток педагогічної освіти у Фінляндії безпосередньо пов'язаний із цілою низкою чинників, серед яких важливе місце посідають введення гнучких i вільних стандартів навчання (курікулуму), які грунтуються на компетентнісній підготовці вчителя.

Так, аналізуючи курікулум педагогічної освіти вчителя середньої школи, представленого у роботі Jakku-Sihvonen R., Tissari V., Uusiautti S. (2007), ми дійшли висновку, що окрім академічної підготовки майбутнього учителя (від 85 до 120 кредитів ECTS у бакалавраті та 60 - 120 кредитів у магістратурі), значна увага надається педагогічному навчанню, на яке виділяється як мінімум 60 кредитів ECTS у бакалавраті й магістратурі. Воно передбачає не лише теоретичну педагогічну підготовку, а й практичне іiї втілення під час проходження навчальних практикумів і контрольованої педагогічної практики у так званих «Педагогічних тренувальних школах» при університетах Фінляндії та пізніше у муніципальних школах. Компоненти курікулуму педагогічного навчання розділені так (за JakkuSihvonen R., Tissari V., Uusiautti S.):

1) теоретичне педагогічне навчання (дидактика, методика навчання i викладання певного предмету, порівняльна педагогіка, педагогічна психологія й соціологія та ін. - 25 - 40 кредитів ECTS);

2) навчання для набуття дослідницької компетентності (3-12 кредитів ECTS), спрямоване на набуття дослідницької готовності майбутніх педагогів до навчання учнів та орієнтоване на оволодіння ними сучасними методами й методиками навчальної діяльності (дослідницько-комунікативна методологія). Практично реалізується під час проходження студентами контрольованої педагогічної практики;

3) контрольована педагогічна практика (20-25 кредитів ECTS), яка проходить на трьох рівнях: інтегрована з теоретичним навчанням і спрямована на закладання навичок дослідницької діяльності; практикум у тренувальних школах під безпосереднім керівництвом викладачів з апробацією методів навчання учнів (у тому числі й дослідницьких) у певній предметній області; практика у муніципальних школах, де студент несе повну відповідальність за свою педагогічну діяльність та здійснює науково-дослідну роботу, враховуючи результати самоаналізу набутого педагогічного досвіду;

4) додаткове навчання (додаткові 1-2 предмети за міждисциплінарним підходом) - до 10 кредитів ECTS.

Таким чином, навчально-дослідницька підготовка майбутніх учителів у Фінляндії займає важливе місце у формуванні їх фахової компетентності та $є$ підгрунтям для подальшого професійного самоудосконалення.

3 вітчизняного досвіду вищої педагогічної освіти вирізняються наукові праці 3 цієї проблемної галузі, здійснені впродовж останніх років. Так, С. В. Стрижак (2005), грунтуючись на особистісно-орієнтованому підході, обгрунтувала модель науково-методичної підготовки вчителів природознавчого напряму, в основу якої поклала виокремленні внутрішні та зовнішні чинники, що мають вплив на процес 
формування складових компонентів цієї підготовки, а також принципи ії реалізації у закладі вищої освіти.

У роботі В. В. Оніпко (2012) визначено перелік фахових компетентностей майбутнього вчителя природничих дисциплін, до якого входять фундаментальна, психолого-педагогічна та методична компетентності. Авторка зазначає, що прикладом метапредметної компетентності може бути природничо-дослідницька компетентність. Вона найбільш повно відображає сучасні вимоги до якості професійної підготовки в аспекті розвитку особистості фахівця. На думку дослідниці, сформувати складові всіх компонентів зазначеної компетентності можливо, застосовуючи системне використання педагогічних технологій в освітньому процесі.

Врахувавши наукові напрацювання та досвід практики застосування навчально-дослідницької підготовки майбутніх педагогів в Україні і за кордоном, ми розробили методичні підходи до створення спеціального освітнього середовища, що сприяє підвищенню якості такої підготовки в освітньому процесі закладів вищої педагогічної освіти. В основу були покладені компетентнісний, міждисциплінарний, проблемно-орієнтований та діяльнісний підходи.

Фахове спрямування підготовки майбутнього учителя природничих дисциплін визначає основоположне значення міждисциплінарного підходу у побудові змісту освітнього процесу і має на меті формування у студентів природничо-наукової картини світу як результату інтеграції фундаментальних знань з біології, фізики, хімії, природознавства. У природничій галузі впродовж останніх десятиліть відбуваються процеси інтеграції й диференціації наук, які, тісно взаємодіючи між собою, забезпечують нові наукові відкриття на межі різних галузей знань.

Компетентнісний підхід ставить завдання формування системи фахових компетентностей майбутнього учителя природничих дисциплін, до яких ми віднесли: предметні компетентності (природничо-наукова, навчальнодослідницька, експериментально-дослідна, здоров'язбережувальна (валеологічна)), психолого-педагогічні компетентності (дидактична, навчальнометодична, виховна, організаційна, психологічна), професійно-комунікативні компетентності (вербально-логічна, інтерактивна, соціально-комунікативна, технічно-змістова) та екологічна компетентність (І. Сяська, 2018). Хоча деякі науковці наголошують на тому, що екологічна компетентність входить до переліку предметних компетентностей саме вчителя природничих дисциплін, оскільки екологія $\epsilon$ галуззю природничих наук. Однак, на наш погляд, такий підхід $\epsilon$ неправильним: екологічну компетентність слід відділяти від предметних компетентностей, як таку, що $є$ підгрунтям для формування суспільної й індивідуальної екологічної культури й свідомості, тому має бути складовою життєвих (ключових) і загальних фахових компетентностей з огляду на наростання світових екологічних проблем.

Проблемно-орієнтований підхід навчально-дослідницької підготовки вчителя передбачає застосування технологій проєктів і проблемного навчання, які дають змогу підвищити iї ефективність. Постановка проблеми теоретичного чи прикладного характеру інтенсифікує експериментально-дослідну діяльність студентів з їі вирішення, зумовлює розвиток креативного мислення, критичного аналізу навчально-професійного матеріалу задля пошуку оптимальних шляхів розв'язання проблемної задачі або виконання індивідуального чи колективного проєкту. Крім того зазначені технології стимулюють розвиток soft-skills навичок: відповідальності, командної роботи, комунікативних вмінь, самоменеджменту й самодисципліни. 
Інноватика у вихованні. Випуск 11. Том 1. 2020.

У свою чергу діяльнісний підхід дає змогу студентам дослідноекспериментальним шляхом поглибити і закріпити теоретичний матеріал на практикумах, активізувати пізнавальний інтерес до природничих наук та реалізувати його під час навчальних і виробничих (педагогічних) практик та в період виконання курсових проєктів і кваліфікаційних робіт.

Обгрунтування підходів до навчально-дослідницької підготовки майбутніх учителів природничих дисциплін, дало змогу визначити форми та засоби іiі реалізації в освітньому процесі закладу вищої освіти. Так, в Рівненському державному гуманітарному університеті з метою якісної професійної підготовки майбутніх учителів природничих наук створено спеціальне освітнє середовище у вигляді організації роботи навчально-методичного центру природничої освіти (рис. 1). До складу центру входять лабораторії навчально-дослідницької підготовки, оснащені сучасним обладнанням для проведення практикумів, лабораторія методик навчання природничих дисциплін, лекційні аудиторії, забезпечені мультимедійним супроводом подачі навчального матеріалу, та лабораторія науково-дослідної роботи студентів. Робота навчально-методичного центру природничої освіти спрямована на активізацію навчально-дослідницької діяльності студентів як засобу формування системи загальних і спеціальних компетентностей майбутніх учителів біології, фізики, хімії, природознавства. 


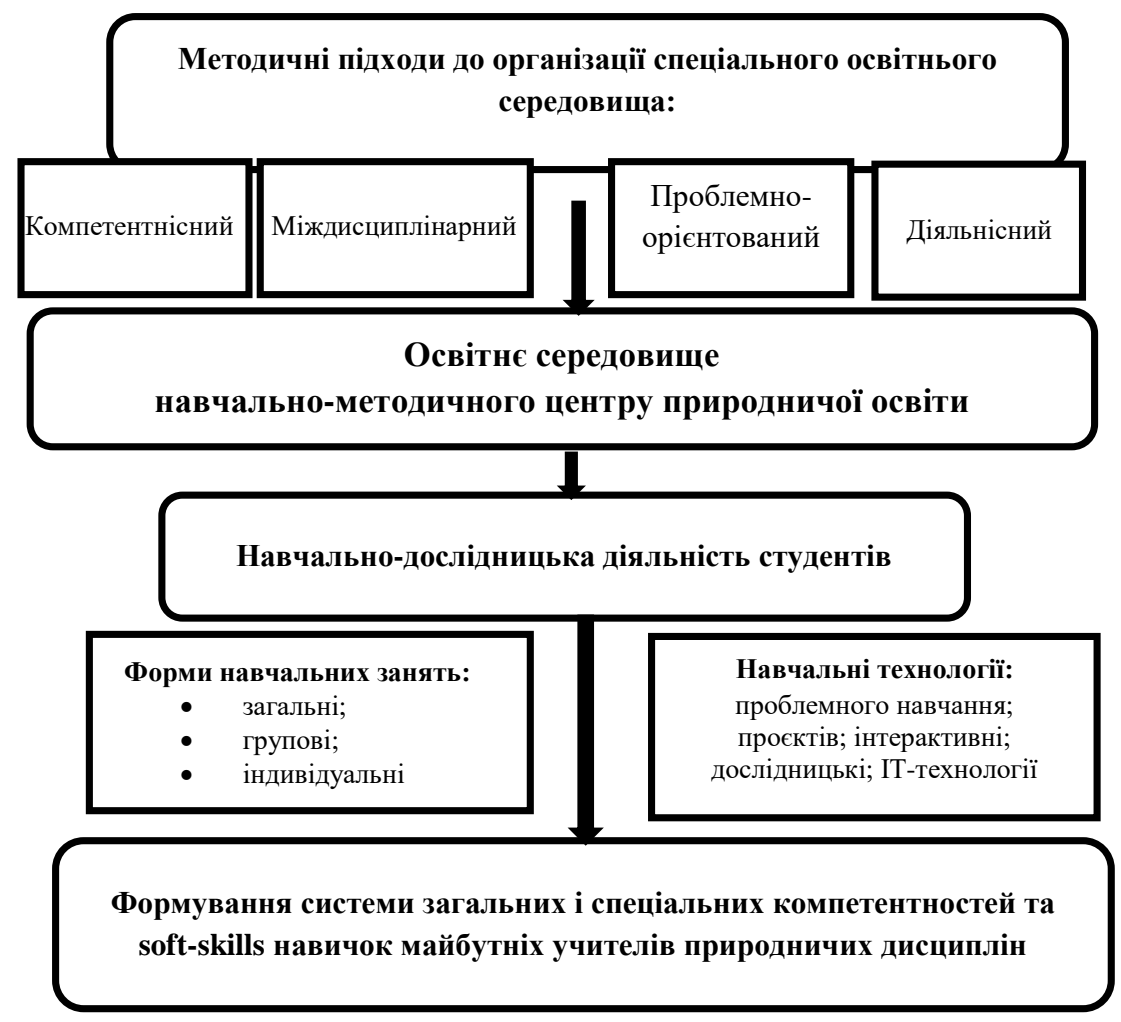

Рис. 1. Модель навчально-дослідницької підготовки майбутніх учителів природничих дисциплін

Зокрема, навчально-дослідницька діяльність студентів 3 використанням сучасного обладнання у лабораторіях центру зумовлює розвиток низки компетентностей: природничо-наукової, навчально-дослідницької, експериментально-дослідної, здоров'язбережувальної, екологічної, навчальнометодичної та інформаційно-комунікаційної. Приміром, використання приладів для проведення фізичних експериментів, потужного оптичного мікробіологічного обладнання, спеціалізованих міні-лабораторій для дослідження хімічного складу води та грунту, а також обладнання для моніторингу функціонального стану організму людини й санітарно-гігієнічних умов навчальних приміщень, якими забезпечені лабораторії центру, дає змогу проводити різноманітні форми навчальних занять студентів, інтенсифікувати науково-дослідну роботу i формувати зазначені компетентності майбутніх учителів природничих дисциплін. Частина обладнання (бінокулярні мікроскопи) має спеціальні пристрої: цифрові камери та різні виходи (USB, Wi-Fi), за допомогою яких можна об'єднати в мережу, тому усі зображення 3 мікроскопів студентів викладач може побачити на мультимедійному екрані або на своєму гаджеті чи ноутбуці. Застосування цифрових технологій посилює мотивацію студентів до більш активної участі в роботі за допомогою цифрових пристроїв, моніторинг роботи всіх студентів 3 власного пристрою без потреби пересування аудиторією, залучення до 
обговорення результатів, спільне використання зображень та відео онлайн. А для студентів - це навчання у звичному цифровому середовищі, спільне використання результатів 3 одногрупниками, робота 3 привабливою новою освітньою технологією, а відтак - інтерес до навчання, швидка допомога викладача, оволодіння інформаційно-комунікаційною компетентністю. У поєднанні 3 ІКтехнологіями на заняттях доцільно поєднувати технології проблемного навчання, проєктів, інтерактивних та дослідницьких технологій. Постановка навчальнодослідницького завдання або проблеми і створення проєкту ії розв'язання з позицій різних природничих дисциплін забезпечує реалізацію міждисциплінарного підходу, як базового, у фаховій підготовці учителів саме природничих дисциплін.

У свою чергу використання різних форм організації навчальних занять у лабораторіях центру: загальних (лекційні, лабораторні, практичні заняття, навчальна практика), групових (консультаційні, заняття наукових гуртків, проєктних груп, тренінги, дискусійні клуби, круглі столи), індивідуальних (тьюторівські заняття, дослідницькі заняття 3 науковим керівником курсових проєктів чи кваліфікаційних робіт) зумовлює розвиток певних soft-skills навичок та загальних компетентностей студентів згідно проєкту TUNING:

- здатність учитися й оволодівати сучасними знаннями, застосовувати знання в практичних ситуаціях;

- здатність до дослідницької діяльності;

- здатність до самостійної роботи;

- $\quad$ здатність до пошуку, оброблення та аналізу інформації з різних джерел;

- здатність генерувати нові ідеї (креативність), розвивати гуманітарне та ноосферне мислення, інтелектуальну та ціннісно-мотиваційну сферу;

- здатність використовувати інформаційні і комунікаційні технології;

- здатність працювати у команді й вміння виявляти міжособистісну комунікацію.

Висновки та перспективи подальших розвідок. Таким чином, організація освітнього середовища у формі роботи навчально-методичного центру природничої освіти дає змогу підвищити якість компетентнісної освіти майбутніх педагогів засобами навчально-дослідницької діяльності і створює можливості для формування трансдисциплінарної моделі фахової підготовки учителів природничих дисциплін. Проведене дослідження не вичерпує коло питань, які необхідно вирішити для якісної підготовки фахівця в галузі природничої педагогічної освіти, та потребує подальшого впровадження інноваційних підходів і технологій в освітній процес закладів вищої педагогічної освіти.

\section{СПИСОК ВИКОРИСТАНИХ ДЖЕРЕЛ} $112 \mathrm{p}$.

Astolfi, J.-P. (1996). Didactique des sciences de la vie et de la terre. Paris: Nathan,

Department for Education and Skills/Teacher Training Agency, (2002). Qualifying to Teach: Professional Standards for Qualified Teacher Status and Requirements for Initial Teacher Training. London: DFES, 20 p.

Котун, К. (2014). Педагогічна освіта Фінляндї у контексті європейського виміру: методичні рекомендації. Київ: Видавництво Ін-ту обдарованої дитини. 60 с.

Jakku-Sihvonen, R., Tissari, V. \& Uusiautti, S. (2008). Curricula for class teachers and for subject teachers - Core elements of the studies in Education. Didacta Varia. Vol 13(2), 2008, pp. 3-16. 
Стрижак, С. (2005). Науково-методичні основи професійної підготовки майбутніх учителів природничих дисииплін у вищих педагогічних навчальних закладаx. Кандидат педагогічних наук. Інститут педагогіки АПН України.

Оніпко, В. (2012). Теоретико-методичні засади підготовки майбутніх учителів природничих дисциплін до професійної діяльності у профільній школі. Доктор педагогічних наук. Черкаський національний університет ім. Богдана Хмельницького.

Сяська, I. (2018). До проблеми впровадження компетентнісного підходу у процес фахової підготовки майбутніх учителів природничих дисциплін. Педагогічні науки: теорія, історія, інноваційні технології. № 10 (84), сс. 179 - 190.

\section{REFERENCES}

Astolfi, J.-P. (1996). Didactique des sciences de la vie et de la terre. Paris: Nathan, $112 \mathrm{p}$.

Department for Education and Skills/Teacher Training Agency, (2002). Qualifying to Teach: Professional Standards for Qualified Teacher Status and Requirements for Initial Teacher Training. London: DFES, $20 \mathrm{p}$.

Kotun, K. (2014). Pedahohichna osvita Finliandii u konteksti yevropeiskoho vymiru: metodychni rekomendatsii [Pedagogical Education in Finland in the Context of the European Dimension: Guidelines]. Kyiv: Vydavnytstvo In-tu obdarovanoi dytyny. $60 \mathrm{s.}$ (in Ukrainian)

Jakku-Sihvonen, R., Tissari, V. \& Uusiautti, S. (2008). Curricula for class teachers and for subject teachers - Core elements of the studies in Education. Didacta Varia. Vol 13(2), 2008, p. 3-16.

Stryzhak, S. (2005). Naukovo-metodychni osnovy profesiinoi pidhotovky maibutnikh uchyteliv pryrodnychykh dystsyplin u vyshchykh pedahohichnykh navchalnykh zakladakh [Scientific and Methodological Bases of Vocational Training of Future Teachers of Natural Sciences in Higher Teacher Education institutions]. Kandydat pedahohichnykh nauk. Instytut pedahohiky APN Ukrainy. (in Ukrainian)

Onipko, V. (2012). Teoretyko-metodychni zasady pidhotovky maibutnikh uchyteliv pryrodnychykh dystsyplin do profesiinoi diialnosti u profilnii shkoli [Theoretical and Methodological Bases of Future Teachers of Natural Disciplines Training for Professional Activity in a Profile School]. Doktor pedahohichnykh nauk. Cherkaskyi natsionalnyi universytet im. Bohdana Khmelnytskoho. (in Ukrainian)

Siaska, I. (2018). Do problemy vprovadzhennia kompetentnisnoho pidkhodu u protses fakhovoi pidhotovky maibutnikh uchyteliv pryrodnychykh dystsyplin [Implementation a Competent Approach in the Process of Future Teachers of Natural Sciences]. Pedahohichni nauky: teoriia, istoriia, innovatsiini tekhnolohii. No 10 (84), s. 179-190. (in Ukrainian) 


\title{
WAYS OF IMPROVING THE QUALITY OF EDUCATIONAL AND RESEARCH TRAINING OF FUTURE NATURAL SCIENCES TEACHERS
}

\author{
Inna Siaska \\ Ph.D., Associate Professor, Doctoral Student \\ at the Department of Theory and Methods of Education, \\ Rivne State University for the Humanities, \\ Rivne, Ukraine \\ ORCID: 0000-0002-6096-1335 \\ e-mail: syaskainna@gmail.com
}

\begin{abstract}
The article is devoted to the problem of vocational training teachers of natural science in Europe and Ukraine. The study highlights the importance of teaching and research training for future teachers in the field of natural sciences and meet current educational needs. It is established that in the context of this problem progressive can be considered the experience of Finland, where the organization of education of teacher of natural sciences is carried out using a multidisciplinary approach and the involvement of pedagogical technologies, which allow in the educational process to combine both theoretical and practical training to a specialist research-oriented practical activity. The methodological approaches to the creation of a special educational environment with the purpose of improving the quality of educational and research training in the educational process of institutions of higher pedagogical education of Ukraine are substantiated: competence, interdisciplinary, problem-oriented and active. The forms (general, group, individual classes), means (educational and research activity) and technologies (problem training, projects, interactive, research, IT technologies) of its realization in the educational process of Rivne State University for the Humanities were determined. It was proved that the students' educational and research activities in the laboratories of the educational and methodological center of natural education lead to the development of a number of professional competences and soft-skills of the future teachers of natural sciences. In particular, natural-scientific, educational-research, experimental-research, health-saving, ecological, educational-methodical and information-communication competency are formed. Thus, the model of educational-research training of future teachers of natural disciplines is substantiated.

Key words: institution of higher teacher education, teacher of natural sciences, educational environment, educational and methodological center of natural education, educational and research activity.
\end{abstract}

